\title{
Faktor - Faktor yang Berhubungan dengan Rendahnya Minat Ibu terhadap Penggunaan Implan
}

\author{
${ }^{1}$ Ayu Lestari, ${ }^{2}$ Annisa Fitri Rahmadini \\ ${ }^{1,2}$ Akademi Kebidanan Prima Husada Bogor \\ Jln. Brigjen H,Saptadji No. 19 Cilendek Barat Bogor, Indonesia \\ Telp. (0251) 8319922 Email: lestariayu328@gmail.com; diniensuwasa@gmail.com
}

\begin{abstract}
Abstrak
Menurut WHO diperkirakan 225 juta perempuan dinegara berkembang ingin menunda atau menghentikan kesuburan tapi tidak menggunakan metode kontrasepsi apapun karena berbagai alasan. Berdasarkan data yang didapat dari Puskesmas Tanah Sareal 2018, dari 1066 peserta KB Aktif, didapatkan rendahnya penggunaan Implan $(6,94 \%)$ jika dibandingkan dengan pil dan suntik. Penelitian ini menggunakan survei analitik secara cross sectional. Populasi dalam penelitian ini adalah seluruh akseptor kb non implan sebanyak 156 orang dan jumlah sampel sebanyak 112 menggunakan Simple Random Sampling. Hasil analisa didapatkan sebagian besar responden berusia $20-35$ tahun $(71,4 \%)$, memiliki tingkat pendidikan tinggi $(57,1 \%)$, memiliki paritas $\leq 2$ anak $(63,4 \%)$, memiliki tingkat pengetahuan kurang $(42,9 \%)$, tidak mendapat dukungan suami $(92,9 \%)$, dan tidak berminat menggunakan implan $(78,4 \%)$. Terdapat hubungan antara usia, paritas, pengetahuan dan dukungan suami sedangkan yang tidak berhubungan adalah tingkat pendidikan ibu. Simpulan hasil penelitian yaitu terdapat hubungan antara usia, paritas, pengetahuan dan dukungan suami. Diharapkan petugas kesehatan dapat meningkatkan informasi mengenai kb khususnya implan agar menambah cakupan akseptor kb.
\end{abstract}

Kata Kunci : Implan, Keluarga Berencana, Minat

\begin{abstract}
According to WHO it is estimated that 225 million women in developing countries want to delay or stop fertility but do not use any contraceptive methods for various reasons. Based on data obtained from the 2018 Tanah Sareal Health Center, out of 1066 active family planning participants, the use of implants was low (6.94\%) compared to pills and injections. This study used an analytical cross sectional survey. The population in this study were 156 non-implant kb acceptors and a total sample of 112 using Simple Random Sampling. The results of the analysis showed that the majority of respondents were 20-35 years old (71.4\%), had a high education level (57.1\%), had parity $\leq 2$ children (63.4\%), had a lack of knowledge (42.9\%)), did not receive husband's support (92.9\%), and was not interested in using implants (78.4\%). There is a relationship between age, parity, knowledge and support of the husband while the unrelated is the level of education of the mother. The conclusion of the research results is that there is a relationship between age, parity, knowledge and husband's support. It is expected that health workers can improve information about family planning especially implants to increase the acceptability of contraception use.
\end{abstract}

Keywords: Implant, Family Planning, Interest 


\section{Pendahuluan}

Menurut World Health Organization (WHO) penggunaan kontrasepsi telah meningkat di banyak bagian dunia, terutama di Asia dan Amerika Latin dan terendah di SubSahara Afrika. Secara global, pengguna kontrasepsi modern telah meningkat tidak signifikan dari 54\% pada tahun 1990 menjadi $57,4 \%$ pada tahun $2014 .^{1}$

Indonesia merupakan sebuah negara berkembang dengan jumlah penduduk sebanyak 261.890.872 jiwa dengan luas wilayah 1.916.862,2 $\mathrm{km}^{2}$ (Kemenkes, 2017). Masalah yang terdapat di Indonesia adalah laju pertumbuhan penduduk yang relatif masih tinggi. Cara untuk menekan jumlah penduduk dengan menggalakan program Keluarga Berencana $(\mathrm{KB}){ }^{2}$

Berdasarkan data dari Profil Kesehatan Indonesia jumlah Pasangan Usia Subur (PUS) di Indonesia pada tahun 2016 sebanyak 48.536.690 jiwa dengan jumlah akseptor KB baru sebanyak 6.663.156 akseptor $(13,73 \%)$ dan akseptor KB aktif berjumlah 36.306 .662 akseptor (74,80\%). Penggunaan kontrasepsi yang paling diminati adalah metode suntik dan pil dibandingkan dengan IUD, Implant, MOW dan MOP. ${ }^{3}$

Jumlah Pasangan Usia Subur di Jawa Barat pada tahun 2016 sebanyak 9.521.667 Jiwa. Dimana jumlah peserta KB aktif sebesar 7.129.900 akseptor (74,88\%). Berdasarkan jumlah akseptor KB aktif pengguna KB Suntik sebesar 3.703.583 akseptor (51,94\%), Pil 1.762 .512 akseptor $(24,72 \%)$, Kondom 129.010 akseptor (1,81\%), IUD 841.841 akseptor (11.81\%), Implant 444.647 (6,24\%), MOW 197.699 akseptor (2,77\%) dan MOP sebesar $(0,71 \%)$. Berdasarkan pengguna KB Aktif Jawa Barat didapatkan pengguna $\mathrm{kb}$ hormonal paling rendah adalah KB Implant. ${ }^{3}$

Berdasarkan Profil Dinas Kesehatan Kota Bogor tahun 2017 tercatat jumlah pasangan usia subur (PUS) di Kota Bogor sebanyak 153.908 jiwa dengan jumlah peserta KB baru sebanyak 16.821 akseptor $(118,87 \%)$ dan jumlah peserta KB Aktif sebanyak 118.410 akseptor (76,94\%). Berdasarkan jumlah peserta KB aktif didapatkan jumlah pengguna IUD sebanyak 22.669 akseptor (14,9\%), MOP 520 akseptor (0,31\%), MOW 4.042 akseptor
(2,56\%), Implant 7.137 akseptor (4,51\%), Kondom 3.387 akseptor (2,01\%), Suntik 58.226 akseptor $(38,1 \%)$, Pil 20.838 akseptor $(13,5 \%)$. Alat kontrasepsi Implant merupakan salah satu alat kontrasepsi yang cakupannya masih rendah di Kota Bogor jika dibandingkan dengan kontrasepsi pil dan suntik. Di Kota Bogor sendiri untuk menambah cakupan peserta KB baru dan KB aktif Implant digalakan suatu program yaitu program Safari Keluarga berencana untuk menambah jumlah akseptor KB baru dan KB aktif Implant di Kota Bogor. ${ }^{4}$

Implan adalah salah satu jenis alat kontrasepsi yang berupa susuk yang terbuat dari sejenis karet silastik yang berisi hormon, dipasang pada lengan atas. ${ }^{15}$ Implan dapat mencegah kehamilan dengan cara mengentalkan lendir serviks sehingga tidak dapat ditembus oleh sperma. ${ }^{5}$

Berdasarkan studi pendahuluan dari Puskesmas Tanah Sareal 2018 jumlah Pasangan Usia Subur di Wilayah Kerja Puskesmas Tanah Sareal sebanyak 1392 Jiwa dan peserta KB aktif sebanyak 1066 akseptor (76,58\%). Berdasarkan jumlah peserta KB aktif didapatkan data yang memakai kontrasepsi IUD sebanyak 250 akseptor $(23,45 \%)$, MOW 51 akseptor (4,78\%), MOP 4 akseptor $(0,37 \%)$, Implan 74 akseptor $(6,94 \%)$, Suntik sebanyak 434 akseptor ( 40,71\%), pil 214 akseptor $(20,07 \%)$ dan kondom 39 akseptor $(3,68 \%)$.

Tujuan penelitian ini adalah untuk mengetahui Faktor-Faktor yang Berhubungan dengan Rendahnya Minat Ibu Terhadap Penggunaan Implan di Kebon Kelapa dan Gang Sapin Wilayah Kerja Puskesmas Tanah Sareal Tahun 2019.

\section{Metode}

Jenis penelitian yang digunakan adalah survey analitik dengan pendekatan cross sectional. Penelitian dilaksanakan di Kebon Kelapa dan Gang Sapin Wilayah Kerja Puskesmas Tanah Sareal pada bulan MaretApril 2019. Populasi pada penelitian ini adalah seluruh akseptor KB non-implan sebanyak 156 orang dan jumlah sampel sebanyak 112 menggunakan Simple Random Sampling. 


\section{Hasil}

Tabel 1. Distribusi Frekuensi Usia, Pendidikan, Paritas, Pengetahuan, Dukungan Suami dan Minat Ibu terhadap Penggunaan Implan

\begin{tabular}{|c|c|c|}
\hline Variabel & $\mathbf{N}$ & $\%$ \\
\hline \multicolumn{3}{|l|}{ Usia } \\
\hline 20-35 Tahun & 80 & 71,4 \\
\hline$<20$ dan $>35$ Tahun & 32 & 28,6 \\
\hline \multicolumn{3}{|l|}{ Pendidikan } \\
\hline Rendah & 48 & 42,9 \\
\hline Tinggi & 64 & 57,1 \\
\hline \multicolumn{3}{|l|}{ Paritas } \\
\hline$\leq 2$ Anak & 71 & 63,4 \\
\hline$>2$ Anak & 41 & 36,6 \\
\hline \multicolumn{3}{|l|}{ Pengetahuan } \\
\hline Baik & 20 & 17,9 \\
\hline Cukup & 44 & 39,3 \\
\hline Kurang & 48 & 42,9 \\
\hline \multicolumn{3}{|l|}{ Dukungan Suami } \\
\hline Mendukung & 70 & 62,5 \\
\hline Tidak Mendukung & 42 & 37,5 \\
\hline \multicolumn{3}{|l|}{ Minat } \\
\hline Berminat & 24 & 21,4 \\
\hline Tidak Berminat & 88 & 78,6 \\
\hline
\end{tabular}

Tabel 2. Hubungan Usia, Pendidikan, Paritas, Pengetahuan, Dukungan Suami dan Minat Ibu terhadap Penggunaan Implan

\begin{tabular}{|c|c|c|c|c|c|c|c|c|}
\hline \multirow[t]{3}{*}{ Variabel } & \multicolumn{7}{|c|}{ Minat Implan } & \multirow{3}{*}{$P$ Value } \\
\hline & \multicolumn{2}{|c|}{ Berminat } & \multicolumn{2}{|c|}{ Tidak Berminat } & \multicolumn{2}{|c|}{ Total } & \multirow[t]{2}{*}{ OR } & \\
\hline & $\mathbf{n}$ & $\%$ & $\mathbf{n}$ & $\%$ & $\mathbf{n}$ & $\%$ & & \\
\hline \multicolumn{9}{|l|}{ Usia } \\
\hline 20-35 Tahun & 13 & 16,2 & 67 & 83,8 & 80 & 100 & \multirow[t]{2}{*}{0,370} & \multirow[t]{2}{*}{0,035} \\
\hline$<20$ dan $>35$ Tahun & 11 & 34,4 & 21 & 65,6 & 32 & 100 & & \\
\hline \multicolumn{9}{|l|}{ Pendidikan } \\
\hline Rendah & 13 & 27,1 & 35 & 72,9 & 48 & 100 & \multirow{2}{*}{1,790} & \multirow{2}{*}{0,270} \\
\hline Tinggi & 11 & 17,2 & 53 & 82,8 & 64 & 100 & & \\
\hline \multicolumn{9}{|l|}{ Pengetahuan } \\
\hline Baik & 12 & 60,0 & 8 & 40,0 & 20 & 100 & \multirow{3}{*}{0,424} & \multirow{3}{*}{0,000} \\
\hline Cukup & 9 & 20,5 & 35 & 79,5 & 44 & 100 & & \\
\hline Kurang & 3 & 6,2 & 45 & 93,8 & 48 & 100 & & \\
\hline \multicolumn{9}{|l|}{ Paritas } \\
\hline$\leq 2$ anak & 8 & 11,3 & 63 & 88,7 & 71 & 100 & \multirow[t]{2}{*}{0,198} & \multirow[t]{2}{*}{0,001} \\
\hline$>2 \mathrm{anak}$ & 11 & 17,2 & 25 & 61,0 & 41 & 100 & & \\
\hline \multicolumn{9}{|l|}{ Dukungan Suami } \\
\hline Mendukung & 21 & 30,0 & 49 & 70,0 & 70 & 100 & \multirow[t]{2}{*}{5,571} & \multirow[t]{2}{*}{0,004} \\
\hline Tidak Mendukung & 3 & 7,1 & 39 & 92,9 & 42 & 100 & & \\
\hline
\end{tabular}

\section{Pembahasan}

\section{Usia}

Berdasarkan tabel 1 dapat diketahui bahwa responden paling banyak berusia 20-35 tahun $(71,4 \%)$ dan paling sedikit berusia $<20$ dan > 35 tahun (28,6\%). Menurut Elisabeth $\mathrm{BH}$ usia adalah umur individu yang terhitung mulai saat dilahirkan sampai berulang tahun. ${ }^{6}$

\section{Pendidikan}

Berdasarkan tabel 1 dapat diketahui bahwa responden paling banyak memiliki tingkat pendidikan tinggi $(57,1 \%)$ dan paling sedikit memiliki pendidikan rendah $(42,9 \%)$. Pendidikan berarti bimbingan yang diberikan seseorang terhadap perkembangan orang 
menuju cita-cita tertentu yang menentukan manusia untuk berbuat dan mengisi kehidupan untuk mencapai keselamatan dan kebahagiaan $^{6}$

\section{Paritas}

Berdasarkan tabel 1 dapat diketahui bahwa responden paling banyak memiliki paritas $\leq 2$ anak $(63,4 \%)$ dan paling rendah memiliki > 2 anak(36,6\%). Paritas atau jumlah anak hidup adalah jumlah anak yang pernah dilahirkan ibu yang masih hidup. ${ }^{7}$

\section{Pengetahuan}

Berdasarkan tabel 1 dapat diketahui bahwa tingkat pengetahuan responden paling banyak memiliki tingkat pengetahuan kurang $(42,9 \%)$ dan paling sedikit memiliki tingkat pengetahuan baik $(17,9 \%)$. Pengetahuan atau kognitif merupakan domain yang sangat penting untuk terbentuknya tindakan seseorang (over behavior). Pengetahuan seseorang terhadap objek mempunyai intensitas atau tingkat yang berbeda-beda. ${ }^{6}$

\section{Dukungan Suami}

Berdasarkan tabel 1 dapat diketahui bahwa responden paling banyak mendapat dukungan suami $(62.5 \%)$ dan paling sedikit adalah responden yang tidak mendapat dukungan suami (37,5\%). Dukungan suami merupakan bentuk motivasi atau support yang diberikan suami kepada seorang istri dalam pemakaian $\mathrm{kb}^{8}{ }^{8}$

\section{Minat Implan}

Berdasarkan hasil penelitian menunjukan bahwa responden paling banyak tidak berminat menggunakan implan $(78,6 \%)$ dan paling sedikit yang berminat menggunakan implan (21,4\%). Menurut Sukardi dalam Susanto (2014) minat adalah suatu kesukaan, kegemaran atau kesenangan akan sesuatu. Adapun menurut Sardiman (2007) minat adalah suatu kondisi yang terjadi apabila seseorang melihat ciri-ciri atau arti sementara situasi yang dihubungkan dengan keinginan atau kebutuhan sendiri. ${ }^{9}$

\section{Hubungan Usia dengan Rendahnya Minat Ibu Terhadap Penggunaan Implan}

Berdasarkan tabel 2 dapat diketahui bahwa yang tidak berminat menggunakan implan ternyata lebih besar pada kelompok usia 20-35 tahun (83,8\%) dibandingkan dengan kelompok usia $<20$ dan $>35$ tahun (65,6\%). Hasil uji statistik Chi-square diperoleh nilai $p$ value $0,035<0,05$ menunjukan terdapat hubungan antara usia dengan rendahnya minat menggunakan implan. Analisis lebih lanjut menunjukan responden yang berusia 20-35 tahun memiliki resiko 0,3 kali untuk tidak berminat menggunakan implan dibandingkan dengan responden yang berusia $<20$ dan $>35$ tahun.

Menurut Notoadmojo ${ }^{10}$ usia merupakan salah satu faktor yang mempengaruhi perilaku seseorang dalam pemakaian alat kontrasepsi, mereka yang berumur tua mempunyai peluang lebih kecil untuk menggunakan alat kontrasepsi dibandingkan dengan yang berumur muda. ${ }^{11}$

\section{Hubungan Pendidikan dengan Rendahnya Minat Ibu Terhadap Penggunaan Implan}

Berdasarkan tabel 2 dapat diketahui bahwa yang tidak berminat menggunakan implan lebih besar pada kelompok responden yang memiliki tingkat pendidikan tinggi sebanyak 53 orang $(84,1 \%)$ dibandingkan yang memiliki tingkat pendidikan rendah sebanyak 35 orang $(71,4 \%)$. Hasil uji statistik Chi-square didapatkan nilai $p$ value $0,270>$ 0,05 yang artinya tidak ada hubungan antara pendidikan dengan minat ibu terhadap penggunaan implan.

Menurut Hartanto ${ }^{12}$ faktor kontrasepsi implan tidak dipilih oleh akseptor karena takut mengalami komplikasi dari pemakaian kontrasepsi implan.

\section{Hubungan Paritas dengan Rendahnya Minat Ibu Terhadap Penggunaan Implan}

Berdasarkan tabel 2 dapat diketahui bahwa yang tidak berminat menggunakan implan lebih besar pada kelompok paritas $\leq 2$ anak sebanyak 63 orang $(88,7 \%)$ dibandingkan dengan kelompok paritas $>2$ anak sebanyak 25 orang (61\%). Hasil uji statistik $C h i$ square didapatkan hasil $p$ value $0,001<0,05$ yang artinya terdapat hubungan antara paritas dengan rendahnya minat ibu terhadap penggunaan implan. Analisis lebih lanjut menunjukan bahwa kelompok paritas $\leq$ 2 anak beresiko 0,1 kali untuk tidak berminat menggunakan implan dibandingkan dengan kelompok paritas > 2 anak. 
Banyaknya anak yang dimiliki adalah merupakan salah satu faktor yang menentukan keinginan suami istri untuk menjadi akseptor KB. Keluarga yang memiliki anak banyak (lebih dari 2 orang) diharapkan untuk memakai kontrasepsi yang efektif dibandingkan keluarga yang baru memiliki anak sedikit (paling banyak 2). ${ }^{7}$

\section{Hubungan Pengetahuan dengan Rendahnya Minat Ibu Terhadap Penggunaan Implan}

Berdasarkan tabel 2 dapat diketahui bahwa ibu yang tidak berminat menggunakan implan ternyata lebih besar pada yang pengetahuannya kurang sebanyak 45 orang $(93,8 \%)$ dibandingkan dengan yang pengetahuannya cukup maupun baik. Hasil uji statistik Rank Spearmandiperoleh nilai $p$ value $=0,000<0,05$. Maka dapat disimpulkan bahwa terdapat hubungan antara tingkat pengetahuan dengan rendahnya minat ibu terhadap penggunaan implan. Analisa tingkat koefisien korelasi adalah 0,424. Hal tersebut menunjukan bahwa hubungan antara pengetahuan dan minat implan memiliki tingkat keeratan yang sedang. Dan nilai positif menunjukan korelasi yang searah, artinya jika pengetahuan meningkat maka minat implan juga meningkat.

Menurut Notoadmodjo (2007) dalam Andria $^{3}$ pengetahuan merupakan salah satu yang penting untuk terbentuknya tindakan seseorang, Maka semakin tinggi pengetahuan akseptor semakin tinggi minat akseptor dalam penggunaan kontrasepsi implan.

\section{Hubungan Dukungan Suami dengan Rendahnya Minat Ibu Terhadap Penggunaan Implan}

Berdasarkan tabel 2 menunjukan bahwa responden paling banyak tidak berminat menggunakan implan ternyata lebih besar pada kelompok yang tidak mendapat dukungan suami (92,9\%) dibandingkan dengan yang mendapat dukungan suami $(70,0 \%)$. Hasil uji statistik Chi square diperoleh hasil $p$-value $=0,004<0,05$. Maka dapat disimpulkan bahwa terdapat hubungan antara dukungan suami dengan rendahnya minat ibu terhadap penggunaan implan. Analisis lebih lanjut menunjukan bahwa ibu yang tidak mendapat dukungan suami beresiko 5,5 kali untuk tidak berminat menggunakan implan dibandingkan dengan yang mendapat dukungan suami.

Dukungan suami berpengaruh besar terhadap pemilihan kontrasepsi yang dipakai istri, bila suami tidak setuju dengan kontrasepsi yang di pakai istrinya maka sedikit istri yang akan memakai kontrasepsi tersebut. ${ }^{14}$

\section{Kesimpulan}

Kesimpulan yang dapat diambil berdasarkan penelitian yang dilakukan di Kebon Kelapa dan Gang Sapin adalah sebagai berikut :

1. Distribusi frekuensi responden berdasarkan usia bahwa sebagian besar responden berusia 20 sampai 35 Tahun sebanyak 80 orang $(71,4 \%)$.

2. Distribusi responden berdasarkan pendidikan bahwa sebagian besar responden memiliki tingkat pendidikan tinggi sebanyak 64 orang $(57,1 \%)$.

3. Distribusi responden berdasarkan paritas bahwa sebagian besar responden memiliki paritas $\leq 2$ anak sebanyak 71 orang $(63,4 \%)$.

4. Distribusi responden berdasarkan pengetahuan bahwa sebagian besar responden yang memiliki tingkat pengetahuan kurang sebanyak 48 orang $(42,9 \%)$.

5. Distribusi responden berdasarkan dukungan suami bahwa sebagian besar responden tidak mendapat dukungan dari suaminya sebanyak 39 orang $(92,9 \%)$.

6. Distribusi responden berdasarkan minat bahwa sebagian besar responden tidak berminat menggunakan implan sebanyak 88 orang $(78,4 \%)$.

7. Terdapat hubungan antara usia dengan rendahnya minat ibu terhadap penggunaan implan.

8. Tidak terdapat hubungan antara pendidikan dengan rendahnya minat ibu terhadap penggunaan implan.

9. Terdapat hubungan antara paritas ibu dengan rendahnya minat ibu terhadap penggunaan implan.

10. Terdapat hubungan antara tingkat pengetahuan ibu dengan rendahnya minat ibu terhadap penggunaan implan.

11.Terdapat hubungan antara dukungan suami dengan rendahnya minat ibu terhadap penggunaan implan. 


\section{Saran}

Saran dalam penelitian ini adalah diharapkan petugas kesehatan dapat meningkatkan informasi mengenai $\mathrm{kb}$ khususnya implan agar menambah cakupan akseptor kb.

\section{Daftar Pustaka}

1. WHO.2014

2. BAPPENAS. Laporan pencapaian tujuan pembangunan milenium indonesia BAPPENAS.2010.Diakses tanggal 5 maret 2019. https://www.bappenas.go.id/files/5413/9148/4109/ Proyeksi_Penduduk_Indonesia_20102035.pdf. 2010

3. Kemenkes RI. Profil kesehatan indonesia 2016. Jakarta : Kemenkes RI. Diakses tanggal 23 Maret 2019.

http://www.depkes.go.id/resources/download/pusd atin/profil-kesehatan-indonesia/Profil-KesehatanIndonesia-2016.pdf. 2016

4. Dinas Kesehatan Kota Bogor. Profil kesehatan kota bogor tahun 2016. Kota Bogor: Dinkes Kota Bogor. Diakses tanggal 10 Maret 2019. http://www.depkes.go.id/resources/download/profi 1/PROFIL_KES_PROVINSI_2016/12_Jabar_2016 .pdf.2016.

5. Everett S. Buku saku kontrasepsi dan kesehatan seksual reproduktif. Jakarta: Penerbit Buku Kedokteran EGC; 2015.

6. Wawan, A dan Dewi, M. Teori dan pengukuran pengetahuan, sikap dan perilaku manusia. Yogyakarta: Nuha Medika. 2016.

7. Musu AB. Faktor - faktor yang berhubungan dengan pemakaian kontrasepsi implan pada akseptor KB di Puskesmas Ciomas kecamatan ciomas, kabupaten bogor tahun 2012. Skripsi. Depok. FKM UI. 2012.

8. Uprianti. Hubungan dukungan suami dengan rendahnya minat ibu dalam pemilihan Alat Kontrasepsi Dalam Rahim (AKDR). Skripsi. Poltekkes Kendari 2018. 2018.

9. Susanto A. Teori belajar dan pembelajaran di sekolah dasar. Jakarta: Prenadamedia Group; 2014.

10. Notoadmodjo S. Metodologi penelitian kesehatan. Jakarta: Rineka Cipta; 2018.

11. Fienalia RA. Faktor - Faktor yang berhubungan dengan penggunaan metode kontrasepsi jangka panjang (MKJP) di wilayah kerja puskesmas pancoran mas kota depok tahun 2011. Skripsi. Depok : FKM UI; 2012.

12. Hartanto H. Keluarga berencana dan kontrasepsi. Jakarta: Pustaka Sinar Harapan; 2013.

13. Andria. Faktor - faktor yang mempengaruhi rendahnya pemakaian $\mathrm{kb}$ implan di desa margamulya wilayah kerja puskesmas rambah samo i. Joernal Maternity and Neonatal Volume 2 no 2.2016 .
14. Hariani P. Rendahnya keikutsertaan pengguna kontrasepsi jangka panjang pada pasangan usia subur.Jurnal Biometrika dan Kependudukan Vol 3 No 1. 2014.

15. Handayani S. Buku ajar pelayanan keluarga berencana. Yogyakarta: Pustaka Rihama; 2015. 